\title{
Cost analysis of endodontic treatment in primary teeth: results from a randomized clinical trial
}

\section{Suzana Cavalcanti Monteiro de OLIVEIRA ${ }^{(a)}$ \\ Isabela FLORIANO(b) iD \\ Tamara Kerber TEDESCO(c) \\ Thaís GIMENEZ(c) \\ José Carlos Pettorossi \\ IMPARATO(a)}

Ana Flávia Bissoto CALVO(a)

(a)Faculdade São Leopoldo Mandic, Graduate Program in Pediatric Dentistry, Campinas, SP, Brazil.

(b) Centro Universitário Uninovafapi, Dentistry Course, Teresina, PI, Brazil.

(c) Universidade Ibirapuera - UNIB, Graduate Program in Dentistry, São Paulo, SP, Brazil.

Declaration of Interests: The authors certify that they have no commercial or associative interest that represents a conflict of interest in connection with the manuscript.

Corresponding Author:

Suzana Cavalcanti Monteiro de Oliveira

E-mail: suzanacmo19@gmail.com

ht1ps://doi.org/10.1590/1807-3107bor-2021.vol35.0126

Submitted: June 5, 2020

Accepted for publication: April 28, 2021

Last revision: June 10, 2021

\begin{abstract}
This study compared the cost of endodontic treatment in primary teeth involving a technique that does not require root canal instrumentation using antibiotic paste (CTZ) with that of the instrumented technique using iodoform paste (GP). This study is part of a randomized, controlled, parallel arm, noninferiority, 1:1 allocation, blinded (patient) multioperator study of 52 primary incisors of children aged 3 to 6 years with caries lesion and pulp involvement. Each technique was performed according to the creators' descriptions. The cost was assessed by analyzing the costs of capital, dental supplies, and professional labor according to the time taken to perform the procedure and the CHEERS guidelines were used to report the cost assessment. Endodontic treatment with CTZ had a 58.33\% lower execution cost than GP (US\$6.73 and US\$16.15, respectively). The t-test showed significant differences between groups regarding treatment time and total cost $(p<0.0001)$. The CTZ technique seems to be more economically viable than GP for endodontic treatment of primary teeth, requiring a shorter treatment time and lower costs.
\end{abstract}

Keywords: Costs and Cost Analysis; Tooth, Deciduous; Pulpectomy; Endodontics.

\section{Introduction}

Pulp therapy of primary teeth aims to maintain the integrity and health of the tooth and the supporting tissues until exfoliation, without any damage to permanent successors. ${ }^{1}$ The treatment is considered successful when it neutralizes the action of microorganisms present in the root canal system, with regression of clinical and radiographic signs and symptoms. ${ }^{2}$ One of the most important aspects for successful treatment is the use of antimicrobial pastes. ${ }^{3,4}$

Deciduous teeth have a distinct anatomy, with many accessory canals, irregular rhizolysis and great microbial diversity, making endodontic treatment problematic, ${ }^{5}$ along with the presence of the permanent successor germ and the difficulty of managing child behavior due to the patient's young age. ${ }^{2}$ Thus, it is essential to use obturation material with a broad spectrum of action, good diffusion, and that does not cause damage to periapical tissues and permanent teeth. ${ }^{6}$ 
Chloramphenicol-Tetracycline-Zinc oxide eugenol (CTZ) antibiotic paste is a material used in endodontic therapies. ${ }^{7}$ Some important advantages of the CTZ paste technique is that it does not require rubber dam isolation of operative field, instrumentation, and root canal obturation. ${ }^{2,7,8}$ A non-instrumental endodontic treatment (NIET), also known as lesion sterilization and tissue repair (LSTR), aims to repair damaged tissues by disinfecting affected pulp and periapical regions with a mixture of antibiotics. ${ }^{9}$ These characteristics reduce the clinical time of therapy, and hence, it is more favorable for pediatric dental care, specifically in the public service and for patients with difficult management. ${ }^{10}$ Although staining of the treated tooth may occur, the literature regarding this is still scarce, but a series of cases with CTZ showed clinical and radiographic success of $100 \%$ and $98 \%$, respectively. ${ }^{2}$ However, few studies have evaluated the clinical and laboratory performance of CTZ paste on primary teeth.

Guedes-Pinto paste, composed of iodoform, camphorated paramonochlorophenol and Rifocort ${ }^{\circledR}$ (rifamycin ointment), was once the most used filling material in Brazilian educational institutions. ${ }^{11,12}$ Classical pulpectomy with debridement and modeling of root canals has been the gold standard treatment for primary teeth with irreversible pulp inflammation or pulp necrosis. ${ }^{1}$ Clinical and radiographic success, after 12 months, with this material was found to be $100 \%$ and $97.1 \%$, respectively. ${ }^{13}$

The therapeutic decision, in addition to being centered on scientific evidence, should also address economic issues, as it generates a cost for patient and may be directly involved with adherence or not to the proposed treatment. ${ }^{14}$ Studies focusing on the cost of treatment are important for public management of government programs; however, we did not find any previous study evaluating the cost of pulpectomy in primary teeth, and the present study is the first to be carried out in Brazil.

Given this scenario, it is relevant to conduct a study that evaluates the non-instrumented technique with CTZ antibiotic paste as a therapeutic option for endodontic treatment of primary teeth. The aim of this study was to evaluate the cost of this treatment, compared with the instrumented technique using iodoform paste.

\section{Methodology}

\section{Study design}

The present study was nested in an umbrella study, registered in Clinical Trials NCT03731975. Its main outcome was the evaluation of the effectiveness of the non-instrumented endodontic techniques. This was a non-inferiority randomized controlled trial with two arms, 1:1 allocation, blinded (patient), in children aged 3 to 6 years, with complete deciduous dentition and carious lesions with pulp involvement. The secondary outcome outlined in this article was the evaluation of the cost of endodontic treatment in primary teeth of a technique that requires no mechanical instrumentation dispensing antibiotic paste (CTZ) compared with an instrumented technique using iodoform paste (GP). The CHEERS ${ }^{15}$ guidelines were used to report the cost assessment.

\section{Ethical considerations}

All subjects assented to participate with consent of legal guardians by signing the consent form. The study was approved by the Research Ethics Committee of Sao Leopoldo Mandic College CEP/CAAE: 65279817.1.0000.5374.

\section{Study site}

The research was conducted by nine examiners in public and private offices in the cities of João Pessoa-PB, Campina Grande-PB, Santa Ines-MA, Caruaru-PE, Aracaju-SE, Porto Velho-RO, Campinas -SP and Florianopolis-SC. The cities are distributed in four regions of Brazil: North, Northeast, Southeast and South. João Pessoa, Aracaju, Maceio, Porto Velho, and Florianopolis are the capital and main business districts of their states, with populations ranging from 88,590 (Santa Ines) to more than 1 million inhabitants (Maceio and Campinas), as estimated in 2018. Florianopolis is the third best Brazilian city in terms of quality of life, with a municipal human development index of $0.847 .{ }^{16}$ Only the cities of Aracaju, Campinas, and Florianopolis have a public water supply fluoridation program. ${ }^{17}$

\section{Operator training}

Operators were trained to perform endodontic treatment with CTZ and GP techniques and to restore 
primary teeth with Fuji $\mathrm{II}^{\circledast}$ resin modified glass ionomer cement (GC America, Illinois, United States of America) through theory class (8-h course load) and laboratory activity (4-h course load). The activity was conducted by teachers of the Master's Program in Pediatric Dentistry, Sao Leopoldo Mandic College, Campinas, SP, Brazil. The oral health assistants were instructed by operators.

\section{Sample calculation and subject selection}

A sample calculation was performed for the primary outcomes. In the secondary outcome, 52 primary incisors were included in the secondary outcome, with 99\% power to analyze the cost and time of treatment, and a significance level of $5 \%$. The sampling unit was a tooth. Only one tooth was selected per child.

Subjects were included in the study if: a) they were aged between 3 and 6 years and 11 months and had complete primary dentition; b) had at least one primary maxillary incisor with untreated caries and pulp involvement; c) consented to participate in the study verbally and through collaborative behavior; and d) parents consented to their participation by signing the Informed Consent Form.

Subjects were excluded from the study if: a) they had caries lesions involving three or more dental surfaces in such a way as to make the restoration difficult or impossible to restore; b) presented internal or external resorption in more than $1 / 3$ of the root length; c) the crypt of the permanent successor tooth was broken; d) had less than $2 / 3$ of the root of the affected tooth; and e) had systemic health problems with oral impairment.

\section{Initial examination}

Initially, anamnesis was completed, caries detection examinations were performed according to the ICDAS index ${ }^{18}$ and PUFA exam. ${ }^{19}$ Scores were recorded. Incisors with dentin caries (ICDAS scores 5 or 6 ) and suspected pulp involvement (PUFA P, F, or A scores) were radiographed using the occlusal technique modified with adult film.

Once eligibility criteria were confirmed, included teeth were treated according to allocation. Treatment duration (endodontic and restorative treatments) and material used were recorded.
The time for endodontic treatment was recorded from access regularization (contour and convenience shape), till coronary chamber cleaning with $70 \%$ alcohol to remove debris, using a digital stopwatch handled by the dental assistant (Table 1).

Subjects who had other treatment needs were referred onwards, and the remaining teeth requiring endodontic treatment followed the same technique.

\section{Randomization sequence and allocation mechanism}

Patients were allocated to one of the treatment groups (CTZ or GP) according to a sequence generated by an external examiner using appropriate statistical software (MedCalc ${ }^{\circledR}$ 15.11, MedCalc Software, Ostend, Belgium), and distributed in sealed opaque brown envelopes. Envelopes were opened immediately after isolation of the operative field.

\section{CTZ Group - Technique with no mechanical instrumentation using antibiotic paste}

The teeth treated with the CTZ technique followed the protocol of Cappiello, ${ }^{7}$ updated by Moura et al. ${ }^{2}$ (Table 1).

\section{GP Group - Instrumented technique using iodoform paste}

The teeth treated by the GP technique followed the protocol of Guedes-Pinto et al., ${ }^{11}$ updated by Mello-Moura et al..$^{12}$ (Table 1).

\section{Cost analysis}

The cost analysis of endodontic treatment considers the payer's perspective. The factors accounted for were capital cost, cost of dental supplies, and cost of labor. The costs were calculated for each sample unit.

For capital costs, the costs of the equipment and instruments necessary to perform the endodontic technique were considered. A linear depreciation calculation was performed with a 3-year shelf-life parameter and an estimated average use time per month of $160 \mathrm{~h}$, according to Hesse et al. ${ }^{20}$

To calculate the cost of the dental supplies, instruments, and equipment used in endodontic therapy of primary teeth, a survey was conducted from October 25 to the October 30 2018, from three 
Table 1. CTZ and GP protocols.

\begin{tabular}{|c|c|c|}
\hline Protocols & $\mathrm{CTZ}$ & GP \\
\hline 1 & \multicolumn{2}{|c|}{ Local anesthesia } \\
\hline 2 & \multicolumn{2}{|c|}{ Complete rubber dam isolation of operative field } \\
\hline 3 & \multicolumn{2}{|c|}{ Removal of carious tissue with dentin excavators } \\
\hline 4 & \multicolumn{2}{|c|}{ Access opening of pulp chamber with diamond round bur } \\
\hline 5 & \multicolumn{2}{|c|}{ Access regularization (contour and convenience shape) with endo- $Z$ bur } \\
\hline 6 & \multicolumn{2}{|c|}{ Turn on the timer } \\
\hline 7 & $\begin{array}{c}\text { Irrigation with } 20 \mathrm{~mL} \text { of sterile saline } 0.9 \% \text { and aspiration with } \\
\text { endo suction }\end{array}$ & $\begin{array}{c}\text { Irrigation with } 20 \mathrm{~mL} \text { of } 1 \% \mathrm{NaOCl} \text { and aspiration with } \\
\text { endo suction }\end{array}$ \\
\hline 8 & \multicolumn{2}{|c|}{ Location of the orifices of the root canals with endodontic exploratory probe \# 47} \\
\hline \multirow{2}{*}{9} & \multirow{2}{*}{ - } & Placement of Endo-PTC paste \\
\hline & & with two drops of $1 \% \mathrm{NaOCl}$ at the orifice \\
\hline 10 & $\begin{array}{c}\text { Irrigation with } 20 \mathrm{~mL} \text { of sterile saline } 0.9 \% \text { and aspiration with } \\
\text { endo suction }\end{array}$ & $\begin{array}{c}\text { Irrigation with } 20 \mathrm{~mL} \text { of } 1 \% \mathrm{NaOCl} \text { and aspiration with } \\
\text { endo suction }\end{array}$ \\
\hline 11 & - & $\begin{array}{c}\text { Manual instrumentation using three K-files alternating with } 20 \mathrm{~mL} \\
\text { of } 1 \% \mathrm{NaOCl} \text { irrigation to each file }\end{array}$ \\
\hline 12 & - & Final irrigation with $10 \mathrm{~mL} 17 \%$ EDTA-T \\
\hline 13 & Pulp chamber drying with sterile cotton ball & Canals drying with sterile paper points \\
\hline 14 & $\begin{array}{l}\text { Insertion of the CTZ paste at the entrance of the root canal } \\
\text { with exploratory endodontic probe \#47, followed by a gentle } \\
\text { pressure with sterile cotton ball. PCTZ was manipulated at the } \\
\text { time of use (1 capsule of PCTZ } 1: 1: 2,2 \text { drops of eugenol) }\end{array}$ & $\begin{array}{l}\text { Canals filling with Guedes-Pinto paste } \\
\text { manipulated at the time of use }(1 \mathrm{~cm} \text { rifamycin ointment, } \\
1 \mathrm{~cm} \text { iodoform [measured in anesthetic tube] and } 2 \text { drops of } \\
\text { camphorated paramonochlorophenol) }\end{array}$ \\
\hline 15 & \multicolumn{2}{|c|}{ Laying of a thin layer of Guta percha } \\
\hline 16 & \multicolumn{2}{|c|}{ Coronary chamber cleaning with $70 \%$ alcohol to remove debris } \\
\hline 17 & \multicolumn{2}{|c|}{ Turn off the timer and record endodontic time (in seconds) } \\
\hline 18 & \multicolumn{2}{|c|}{ Restoration with resin modified glass ionomer cement } \\
\hline
\end{tabular}

different Brazilian dental suppliers. A local dental supplier in João Pessoa/PB (Saúde Dental) and two national dental suppliers (Dental Cremer and Dental Speed) and the prices were averaged. CTZ and rifamycin were handled in specific pharmacies, Formula \& Ação (Sao Paulo, Brazil) and Buenos Ayres (Sao Paulo, Brazil), respectively. The cost survey was performed in the same period as the survey of other consumables. Subsequently, cost per dose used for each consumable material was calculated.

The cost of professional labor took into consideration the amount of US\$27.02 per hour of work, according to the dental office cost spreadsheet. The clinical hour value was calculated by the average cost of the operators, according to Braga et al. ${ }^{21}$ which was based on the time taken to perform the endodontic treatment.

Data normality was analyzed using the Shapiro-Wilk test. Comparisons between the groups were made using an independent-sample t-test, with a significance level of 5\%. SPSS statistical software version 25 (IBM Corp., Armonk, USA) was used for statistical analysis.

\section{Results}

A total of 1,127 children, aged 3 to 6 years, were invited to participate in the study. After analyzing the eligibility criteria, 52 children were included and divided according to the allocation sequence into two groups: 26 in the CTZ group and 26 in the GP group. Fifty-two teeth were analyzed (Figure 1).

The CTZ group consisted of $46.15 \%$ female and $53.85 \%$ male children, with $84.62 \%$ aged between 3 and 5 years. The GP group comprised 53.85\% females and $46.15 \%$ males, with $73.08 \%$ aged between 3 and 5 years. Tooth \#52 most frequently required endodontic treatment (Table 2). 


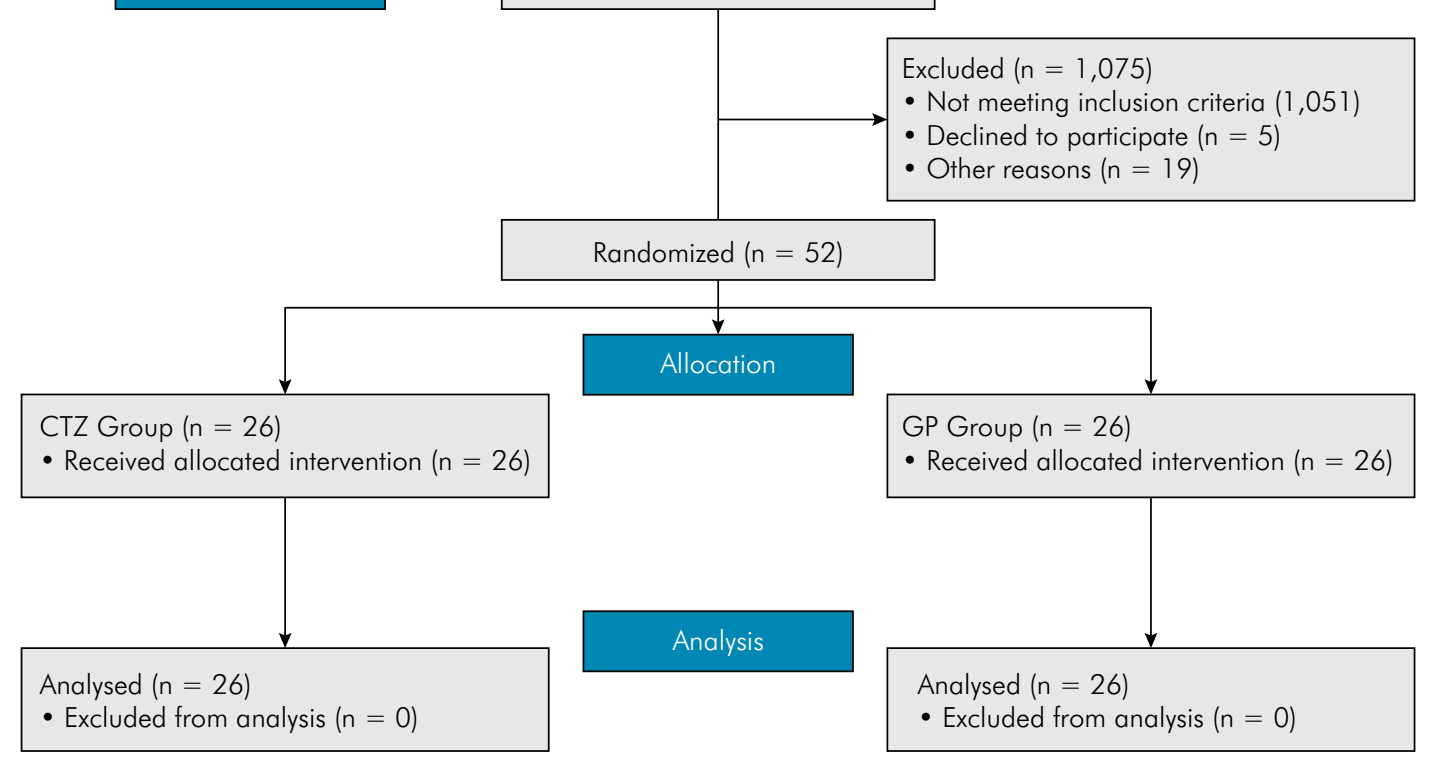

Figure 1. Flow chart of the study design.

Table 2. Initial sample characteristic.

\begin{tabular}{lcc}
\hline \multirow{2}{*}{$\begin{array}{l}\text { Sample } \\
\text { characteristic }\end{array}$} & \multicolumn{2}{c}{ Frequency $n(\%)$} \\
\cline { 2 - 3 } Sex & CTZ Group $(n=26)$ & GP Group $(n=26)$ \\
$\quad$ Female & $12(46.15 \%)$ & $14(53.85 \%)$ \\
Male & $14(53.85 \%)$ & $12(46.15 \%)$ \\
Age range (years) & & \\
$3-4$ & $11(42.31 \%)$ & $10(38.46 \%)$ \\
$4-5$ & $11(42.31 \%)$ & $9(34.62 \%)$ \\
$5-6$ & $3(11.54 \%)$ & $7(26.92 \%)$ \\
+6 & $1(3.84 \%)$ & $0(0 \%)$ \\
Treated tooth & & $15(57.69 \%)$ \\
52 & $11(42.31 \%)$ & $5(19.23 \%)$ \\
51 & $5(19.23 \%)$ & $2(7.69 \%)$ \\
61 & $8(30.77 \%)$ & $4(15.39 \%)$ \\
62 & $2(7.69 \%)$ & \\
\hline
\end{tabular}

The mean time spent on endodontic treatment with the CTZ technique was significantly shorter than that required for GP $(p<0.0001)$ (Figure 2). Cost analysis of working time was calculated according to the time spent in each procedure (US\$ 5.47) for endodontic treatment with CTZ and US\$ 12.45 , for GP, with a significant difference between the cost of the techniques $(\mathrm{p}<0.0001)$ (Table 3).
Table 3. Total cost analysis of endodontic treatment performed in the CTZ and GP groups.

\begin{tabular}{|c|c|c|c|c|}
\hline \multirow{2}{*}{ Expenses } & \multicolumn{2}{|c|}{ CTZ Group (U\$) } & \multicolumn{2}{|l|}{ GP Group (U\$) } \\
\hline & Mean $( \pm \mathrm{SD})$ & $\%$ & Mean $( \pm$ SD) & $\%$ \\
\hline Dental supplies & $0.98( \pm 0.07)$ & 15 & $3.07( \pm 0.13)$ & 19 \\
\hline $\begin{array}{l}\text { Depreciation } \\
\text { (Equipment and } \\
\text { Instruments) }\end{array}$ & $0.28( \pm 0.16)$ & 4 & $0.63( \pm 0.24)$ & 4 \\
\hline Working time cost & $5.47( \pm 3.13)(C)$ & 81 & $12.45( \pm 4.46)(\mathrm{D})$ & 77 \\
\hline Total & $6.73( \pm 0.89)(E)$ & & $16.15( \pm 4.69)(F)$ & \\
\hline
\end{tabular}

The cost of dental supplies used for endodontic therapy in the CTZ group was US\$ 0.98 , and in the GP group was US $\$ 3.07$. The cost of the instruments needed to perform endodontic therapy with GP was US\$17.29, while there was no instrument cost required for procedure performed with CTZ (Table 4).

The linear depreciation calculation of dental equipment and instruments was calculated according to the time spent on endodontic treatment at US\$ 0.28 , and US\$ 0.63, respectively, for the CTZ and GP groups (Table 4).

The final cost analysis of endodontic treatment performed with CTZ group was US\$ 6.73, and the GP group was US\$16.15, considering dental supplies 
used, depreciation of the instruments and equipment, and professional's clinical time according to the time spent in each procedure (Table 3). The t-test showed significant differences between groups regarding treatment time and total cost $(\mathrm{p}<0.0001)$ (Figure 2$)$.

\section{Discussion}

Many materials and techniques are used in the endodontic treatment of deciduous teeth with irreversible pulpitis and pulp necrosis. However,

Table 4. Description of absolute values of dental supplies, instruments and equipment used in endodontic treatments performed in the CTZ and GP groups.

\begin{tabular}{|c|c|c|c|c|c|}
\hline \multirow{2}{*}{ Dental supplies / Instruments / Equipment } & \multirow{2}{*}{ Unit cost (U\$) } & \multicolumn{2}{|c|}{ CTZ Group } & \multicolumn{2}{|c|}{ GP Group } \\
\hline & & Mean* & Cost (U\$) & Mean* & Cost (U\$) \\
\hline CTZ (capsule) & 0.57 & 1 & 0.57 & 0 & - \\
\hline Camphorated paramonochlorophenol (drop) & 0.01 & 0 & - & 1.85 & 0.02 \\
\hline EDTA $(10 \mathrm{~mL})$ & 0.63 & 0 & - & 1.04 & 0.66 \\
\hline Endo-PTC $(1 \mathrm{~cm})$ & 0.25 & 0 & - & 1 & 0.25 \\
\hline Eugenol (goat) & 0.01 & 1.88 & 0.02 & 0 & - \\
\hline lodoform $(1 \mathrm{~cm})$ & 0.98 & 0 & - & 1 & 0.98 \\
\hline Matrix band (unit) & 0.96 & 0 & - & 0 & - \\
\hline $1 \% \mathrm{NaOCl}(20 \mathrm{~mL})$ & 0.04 & 0 & - & 3.35 & 0.13 \\
\hline Rifamycin $(1 \mathrm{~cm})$ & 1.03 & 0 & - & 1 & 1.03 \\
\hline sterile saline $0.9 \%(20 \mathrm{~mL})$ & 0.21 & 1.88 & 0.39 & 0 & - \\
\hline Wedge (unit) & 0.10 & 0.04 & - & 0 & - \\
\hline Total dental supplies & & & 0.98 & & 3.07 \\
\hline K-file & 14.39 & 0 & - & 1 & 14.39 \\
\hline Endo ruler & 2.90 & 0 & - & 1 & 2.90 \\
\hline Total instruments & & & 0.00 & & 17.29 \\
\hline Dental chair & $5,557.71$ & 1 & $5,557.71$ & 1 & $5,557.71$ \\
\hline Stools & $2,58.76$ & 2 & 517.52 & 2 & 517.52 \\
\hline Air Compressor & $1,278.26$ & 1 & $1,278.26$ & 1 & $1,278.26$ \\
\hline High Low Speed Hand Kit & 514.41 & 1 & 514.41 & 1 & $5,14.41$ \\
\hline Total equipment & & & $7,867.90$ & & $7,867.90$ \\
\hline TOTAL & & & $7,868.88$ & & $7,888.26$ \\
\hline
\end{tabular}
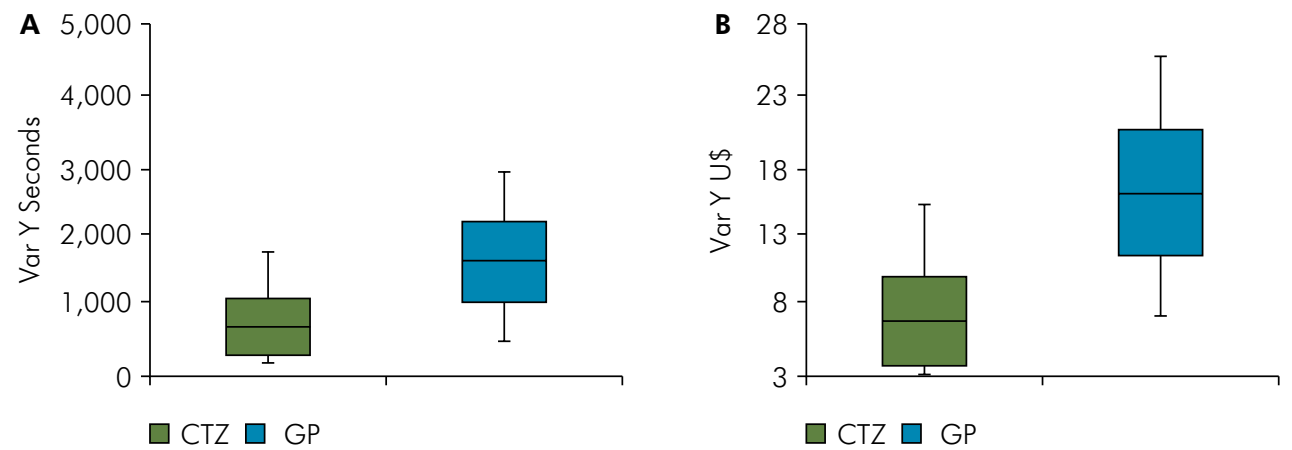

*Different capital letters indicate statistical difference between the evaluated techniques $(p<0.001)$.

Figure 2. Boxplot chart of treatment time (a) and total cost (b) amongst the two groups evaluated (CTZ; GP) (p < 0.001$)$. 
systematic reviews have shown that there is no superiority between techniques.

Tedesco et al. ${ }^{22}$ did not observe differences between pulpectomy, with mechanical cleaning and chemical disinfection of the root canals, and NIET or LSTR. However, the level of certainty of the evidence according to the GRADE scale was very low, with only 2 articles included in the meta-analysis, with a high confidence interval and heterogeneity. Duarte et al. ${ }^{9}$ found no significant difference in the meta-analysis between LSTR and conventional pulpectomy treatment. The amount of evidence according to the GRADE scale was moderate for clinical criteria and moderate to very low for radiographic criteria. We must infer carefully from these results as the data refer to only six studies and only one used CTZ paste. According to Coll et al., ${ }^{23}$ lesion sterilization tissue repair had limited indication for teeth with resorbed roots, but the CTZ paste was not evaluated.

Based on the available evidence, AAPD ${ }^{1}$ included LSTR as an endodontic treatment option for primary teeth with irreversible pulpitis or pulp necrosis, being the technique of choice in cases of root resorption and when the tooth needs to be kept in the cavity for up to one year. However, the paste usually used in the technique is $3 \mathrm{Mix}$, composed of clindamycin (which can be replaced by minocycline), metronidazole and ciprofloxacin. Lokade et al. ${ }^{24}$ evaluated the clinical and radiographic success of LSTR with the CTZ and $3 \mathrm{Mix}$ paste and found no significant differences, concluding that both are effective as an alternative to pulpectomy on primary teeth.

The costs of dental treatment depend on the complexity of the technique and the material used. ${ }^{25}$ Endodontic therapy with a non-instrumented technique and use of antibiotic paste has a simple implementation protocol and reduces the costs involved in the classical endodontic technique, which consists of performing the working length of roots, instrumentation, irrigation, aspiration and obturation of root canals. ${ }^{26,27}$ For Silva et al., ${ }^{28}$ manual instrumentation of root canals, despite being the most widely accepted and used method for canal debridement and modeling, is time consuming and may result in iatrogenic errors. Optimization of the traditional endodontic technique with the use of rotating mechanical and apex locators has advantages such as reduced clinical time, increased patient comfort, and less need for behavioral cooperation of children, ${ }^{29,30}$ however, it increased the costs due to the need to purchase necessary equipment for its accomplishment.

Dental cost analyses are fundamental for dentists, patients, and health managers. The main causal factor of the increased cost of endodontic therapy for primary teeth is the time taken to perform it. It was $56.08 \%$ shorter with the CTZ technique, with a significant difference $(p<0.0001)$ (Figure 2). Time directly impacts the professional's hour-clinical costs, in addition to the depreciation of equipment, and instruments used in each technique. Considering these facts and that the useful life of dental instruments is approximately 3 years (depreciation rate), ${ }^{20}$ we can explain the significant difference found between the groups evaluated. The mean time spent on endodontic treatment with CTZ group was significantly shorter than GP group. This may be justified by the ease of non-instrumented technique. Moreover, from the perspective of clinical practice, a greater number of patients can receive dental treatment or more procedures can be performed on the same patient when opting for a simplified endodontic technique.

The cost of professional clinical time for procedures performed with the CTZ group (US\$ 5.47) was significantly lower than that of the GP group (US\$ 12.45), corresponding to $81 \%$ and $77 \%$ of the total direct cost (Table 3). Thus, it can be said that endodontic therapy performed with CTZ was $56.06 \%$ cheaper than performed with GP in relation to professional labor.

The cost of endodontic therapy with CTZ was $58.33 \%$ lower than that of the GP technique, with a significant difference $(\mathrm{p}<0.0001)$ (Figure 2). Although the CTZ technique can be performed without rubber dam isolation of the operative field, in the present study, both groups received the same type of isolation to minimize any bias in the studied outcomes. In this study, the time taken to perform local anesthesia and absolute isolation of the treated tooth were not recorded; hence, this was considered a limitation of the study. However, if we consider that the CTZ technique can be performed under relative isolation and without the need for local anesthesia, it is possible 
to suggest that the total time spent on the GP technique would be even longer than that of the CTZ technique. Regarding the cost of materials needed to perform endodontic therapy, the CTZ technique was lower, further increasing the differences between the groups. An alternative method of assessing this variable would be to conduct further studies comparing the direct costs of endodontic therapy without anesthesia and absolute isolation.

Public Health Services lack simplified treatment protocols that can be performed by general practitioners, reducing the demand for certain dental treatments. ${ }^{8}$ Currently, in many healthcare systems, primary teeth do not receive endodontic treatment due to complexity of the technique. ${ }^{31}$ Failure to treat a primary tooth with irreversible pulpitis or pulp necrosis can damage the permanent successor and negatively impact the child's oral health and quality of life. ${ }^{32}$ The therapy with antibiotic paste as an alternative, particularly for uncooperative children and limited resourced areas, require no mechanical instrumentation. The procedure is simple, requires only one visit and is not time-consuming. ${ }^{25}$

Dental specialty centers (DSCs) were created to expand and qualify the offer of specialized dental services in Brazil, but the inclusion of pediatric dentists in the teams has not yet been regulated. ${ }^{33}$ Children are cared for by primary care professionals, often non-specialists. A simplified endodontic technique could be performed by these professionals to avoid early loss of deciduous teeth due to their lack of treatment.

The world population continues to suffer from the consequences of untreated oral conditions. This seriously affects children's school performance and adult productivity in their work. Righolt et al. ${ }^{34}$ reported an overall cost of US $\$ 0.90$ billion for lost productivity due to untreated caries lesions in primary teeth. CTZ can help overcome some of these barriers, as it is easy to implement, acceptable to patients and parents, and economically viable.

The cost of the procedure is the primary factor for the choice of treatment by the patient. ${ }^{14}$ Reducing the cost of a treatment may allow the patient to afford it and the health service to offer this procedure. ${ }^{35}$ Selecting the intervention that offers an equilibrium between effectiveness and financial resources becomes crucial in today's low income, tight budget world. ${ }^{36}$ Cost analysis studies are important for government programs, helping in deciding which treatment alternatives can be offered to a population and hence, broadening the judgment base ${ }^{37}$ The low cost is one of the factors that makes a treatment a viable alternative in the establishment of health promotion programs and public policies. ${ }^{20,38}$

There are numerous treatment possibilities, techniques, and materials available for the development of a treatment plan. The professional should offer the patient or, in the case of pediatric dentistry, to his or her guardian, the opportunity to choose the best available treatment. This, in turn, should always be based on the best possible evidence, informing them about the advantages and disadvantages of each technique, complications that may occur, and the time and estimated cost of each treatment option. ${ }^{14,39}$

There are many advantages of adopting CTZ for endodontic treatment of primary teeth in public health services; ${ }^{40}$ however, similar to other endodontic techniques available, it still has a low level of scientific evidence ${ }^{2}$. Further randomized clinical studies are recommended to increase the strength of the available evidence. Its use would also be beneficial in children with difficult behavior management and in patients with special needs, due to the simplicity of the technique that reduces the patient's chair time.

There are few RCTs using the CTZ paste, but its antimicrobial capacity has been evaluated and proven in several in-vitro studies. ${ }^{3,4,6,40}$ The great disadvantage of NIET with CTZ paste is the possible change in the color of the crown. ${ }^{41}$ This browning is caused by the presence of tetracycline in the paste composition. However, a well-executed technique, with placing the CTZ paste only at the entrance of the root canal and cleaning the coronary chamber can reduce this risk.

The study by Abukabbol et al. ${ }^{42}$ evaluated the cost of pulpotomies with bioactive cement and crowns on primary teeth but limited the research to the cost of dental material, disregarding the time factor. This is a fundamental factor in our analysis of the cost of pulpectomy. A treatment that requires less time to be performed allows more treatments to be performed on the same patient or other patients to be seen by the dentist. 
The main limitations of this study are the low comparability rate of cost studies with other countries due to the difference in currencies and the variability in the price of dental supplies. Despite this being a multi-operator study, the results were not very heterogeneous. This fact can be explained by the simplicity of the technique, the theoretical and practical training carried out, and the fact that all operators are specialists and master's students in pediatric dentistry. The patient was blinded to the study. Blinding of the operator was not possible because of the endodontic techniques, the manipulation of the materials used, and the radiographic images differed between CTZ and GP.

The NIET protocol with CTZ paste recommends the use of relative isolation of the operative field. In this study, the two techniques (CTZ and GP) were performed with absolute isolation to avoid the risk of bias. The possibility of using relative isolation makes the CTZ technique even simpler. However, absolute isolation has advantages such as biosafety, maintaining an aseptic environment, reducing the risk of accidents, and better quality of the services performed. ${ }^{43}$

Power, in biostatistics, is the probability of obtaining a significant result when there is a real difference between treatments. Our study had a sample of 52 primary incisors, with $99 \%$ power and a $5 \%$ significance level.
From the cost analysis alone, we cannot state which is the most suitable for endodontic therapy of primary teeth. Other factors of equal or greater clinical relevance, such as efficacy, impact on quality of life, availability of materials, acceptability, age and collaboration of the child, must be considered. This would allow the dentist to choose appropriate treatment which best meets the patient's needs. The available literature is scarce about studies concerning the cost analysis of endodontic treatments in primary teeth. This result is unprecedented and favourable to non-instrumented endodontic technique using antibiotic paste.

\section{Conclusion}

Endodontic therapy with the non-instrumented technique and antibiotic paste (CTZ) for the treatment of primary teeth requires shorter treatment time and lower costs than the instrumented technique and iodoform paste (GP). Further studies are required to confirm these results.

\section{Acknowledgments}

We sincerely thank the masters Claudia Regina Lima Ramagem, Gerana Araujo de Lucena Lira, Isabel Cristina Leite Albuquerque, Ivana Aguiar Ferreira, Marta Verônica Araújo Souza, Milena Sierra Drumond da Costa, Rafaela Cavalcanti Amaral, and Sandra Regina Pereira Silvestre for sharing their samples.

\section{References}

1. American Academy of Pediatric Dentistry. Guideline on pulp therapy for primary and immature permanent teeth. Pediatr Dent. 2016 Oct;38(6):280-8.

2. Moura LFD, Lima MD, Lima CC, Machado JI, Moura MS, Carvalho PV. Endodontic treatment of primary molars with antibiotic paste: a report of 38 cases. J Clin Pediatr Dent. 2016;40(3):175-7. https://doi.org/10.17796/1053-4628-40.3.175

3. Piva F, Faraco-Junior IM, Feldens CA, Estrela CR. Antimicrobial action of root canal filling materials for primary teeth using the agar diffusion method: an in vitro study. Pesq Bras Odontoped Clin Integr. 2009;9(1):13-7. https://doi.org/10.4034/1519.0501.2009.0091.0003

4. Oliveira SM, Omena AL, Lira GA, Ferreira IA, Imparato JC, Calvo AF. Do different proportions of antibiotics in the CTZ paste interfere with the antimicrobial action? In vitro study. Pesqui Bras Odontopediatria Clin Integr. 2019;19(1):e4801. https://doi.org/10.4034/PBOCI.2019.191.115

5. Ahmed HM. Anatomical challenges, electronic working length determination and current developments in root canal preparation of primary molar teeth. Int Endod J. 2013 Nov;46(11):1011-22. https://doi.org/10.1111/iej.12134

6. Amorim LF, Toledo OA, Estrela CR, Decurcio DA, Estrela C. Antimicrobial analysis of different root canal filling pastes used in pediatric dentistry by two experimental methods. Braz Dent J. 2006;17(4):317-22. https://doi.org/10.1590/S0103-64402006000400010 
7. Cappiello J. Tratamientos pulpares en incisivos primários. Rev Circ Od Ros. 1964;52(4):133-45.

8. Siegl RC, Lenzi TL, Politano GT, Benedetto M, Imparato JC, Pinheiro SL. Two endodontics techniques analysis in primary molars with fistula. RGO. 2015 June;63(2):18794. http://doi.org/10.1590/1981-863720150002000082990

9. Duarte ML, Pires PM, Ferreira DM, Pintor AV, Neves AA, Maia LC, et al. Is there evidence for the use of lesion sterilization and tissue repair therapy in the endodontic treatment of primary teeth? A systematic review and meta-analyses. Clin Oral Investig. 2020 Sep;24(9):2959-72. https://doi.org/10.1007/s00784-020-03415-0

10. Zacharczuk GA, Toscano MA, López GE, Ortolani AM. Evaluation of 3Mix-MP and pulpectomies in non-vital primary molars. Acta Odontol Latinoam. 2019 Apr;32(1):22-8.

11. Guedes-Pinto AC, Paiva JG, Bozzola JR. Tratamento endodôntico de dentes decíduos com polpa mortificada. Rev Assoc Paul Cir Dent. 1981 May-Jun;35(3):240-4.

12. Mello-Moura AC, Fanaro J, Nicoletti MA, Mendes FM, Wanderley MT, Guedes-Pinto AC. Variability in the proportion of components of iodoform-based Guedes-Pinto paste mixed by dental students and pediatric dentists. Indian J Dent Res. 2011 Nov-Dec;22(6):781-5. https://doi.org/10.4103/0970-9290.94668

13. Cassol DV, Duarte ML, Pintor AV, Barcelos R, Primo LG. lodoform Vs calcium hydroxide/zinc oxide based pastes: 12-month findings of a randomized controlled trial. Braz Oral Res. 2019 Feb;33:e002. https://doi.org/10.1590/1807-3107bor-2019.vol33.0002

14. Christensen GJ. Do your patients know the alternatives for their oral care? J Am Dent Assoc. 2012 Dec;143(12):1353-5. https://doi.org/10.14219/jada.archive.2012.0099

15. Husereau D, Drummond M, Petrou S, Carswell C, Moher D, Greenberg D, et al. Consolidated Health Economic Evaluation Reporting Standards (CHEERS) statement. Int J Technol Assess Health Care. 2013 Apr;29(2):117-22. https://doi.org/10.1017/S0266462313000160

16. Instituto Brasileiro de Geografia e Estatística. Cidades. Rio de Janeiro: Instituto Brasileiro de Geografia e Estatística; 2018 [cited 2018 Dec 8]. Available from: https://cidades.ibge.gov.br/brasil/pb

17. Frazão P, Narvai PC. Vigifluor - Cobertura e vigilância da fluoretação da água no Brasil: municípios com mais de 50 mil habitantes. São Paulo: Faculdade de Saúde Pública da USP; 2017. https://doi.org/10.11606/9788588848252

18. Ismail Al, Pitts NB, Tellez M, Baneriee A, Deery C, Douglas G, et al. The International Caries Classification and Management System (ICCMS ${ }^{\text {TM }}$ ): an example of a caries management pathway. BMC Oral Health. 2015;15(S1 Suppl 1):S9. https://doi.org/10.1186/1472-6831-15-S1-S9

19. Monse B, Heinrich-Weltzien R, Benzian H, Holmgren C, Van Palenstein Helderman W. PUFA: an index of clinical consequences of untreated dental caries. Community Dent Oral Epidemiol. 2010 Feb;38(1):77-82. https://doi.org/10.1111/j.1600-0528.2009.00514.x

20. Hesse D, Araujo MP, Olegário IC, Innes N, Raggio DP, Bonifácio CC. Atraumatic restorative treatment compared to the hall technique for occluso-proximal cavities in primary molars: study protocol for a randomized controlled trial. Trials. 2016 Mar;17(1):169. https://doi.org/10.1186/s13063-016-1270-z

21. Braga MM, Machado GM, Rocha ES, ViganÓ ME, Pontes LR, Raggio DP. How can we associate an economic evaluation with a clinical trial? Braz Oral Res. 2020;34 Suppl 2:e076. https://doi.org/10.1590/1807-3107bor-2020.vol34.0076

22. Tedesco TK, Reis TM, Mello-Moura AC, Silva GS, Scarpini S, Floriano I, et al. Management of deep caries lesions with or without pulp involvement in primary teeth: a systematic review and network meta-analysis. Braz Oral Res. 2020 Nov;35:e004. https://doi.org/10.1590/1807-3107bor-2021.vol35.0004

23. Coll JA, Vargas K, Marghalani AA, Chen CY, AIShamali S, Dhar V, et al. A systematic review and meta-analysis of nonvital pulp therapy for primary teeth. Pediatr Dent. 2020 Jul;42(4):256-461.

24. Lokade A, Thakur S, Singhal P, Chauhan D, Jayam C. Comparative evaluation of clinical and radiographic success of three different lesion sterilization and tissue repair techniques as treatment options in primary molars requiring pulpectomy: An in vivo study. J Indian Soc Pedod Prev Dent. 2019 Apr-Jun;37(2):185-91. https://doi.org/10.4103/JISPPD.JISPPD_6_19

25. Schwendicke F, Stolpe M, Innes N. Conventional treatment, Hall Technique or immediate pulpotomy for carious primary molars: a cost-effectiveness analysis. Int Endod J. 2016 Sep;49(9):817-26. https://doi.org/10.1111/iej.12537

26. Oliveira MA, Costa LR. Desempenho clínico de pulpotomias com pasta CTZ em molares decíduos: estudo retrospectivo. ROBRAC. $2006 ; 15(40)$.

27. Zacharczuk GA, Toscano MA, López GE, Ortolani AM. Evaluation of 3Mix-MP and pulpectomies in non-vital primary molars. Acta Odontol Latinoam. 2019 Apr;32(1):22-8.

28. Silva LA, Leonardo MR, Nelson-Filho P, Tanomaru JM. Comparison of rotary and manual instrumentation techniques on cleaning capacity and instrumentation time in deciduous molars. J Dent Child (Chic). 2004 Jan-Apr;71(1):45-7.

29. Mello-Moura AC, Borelli T, Matos R, Bonini GC, Moura-Netto C. [How can we optimize endodontics in primary teeth? A reported case]. Rev Assoc Paul Cir Dent. 2013 Jan-Mar;67(1):50-5. Portuguese.

30. Manker A, Solanki M, Tripathi A, Jain ML. Biomechanical preparation in primary molars using manual and three NiTi instruments: a cone-beam-computed tomographic in vitro study. Eur Arch Paediatr Dent. 2020 Apr;21(2):203-13. https://doi.org/10.1007/s40368-019-00474-0 
31. Schwendicke F, Frencken J, Innes N. Clinical Recommendations on carious tissue removal in cavitated lesions. Monogr Oral Sci. 2018;27:162-6. https://doi.org/10.1159/000487843

32. Barja-Fidalgo F, Moutinho-Ribeiro M, Oliveira MA, Oliveira BH. A systematic review of root canal filling materials for deciduous teeth: is there an alternative for zinc oxide-eugenol? ISRN Dent. 2011;2011:367318. https://doi.org/10.5402/2011/367318

33. Ministério da Saúde (BR). Secretaria de Atenção Primária à Saúde. Brasil sorridente. Brasília, DF: Ministério da Saúde; 2020 [cited 2020 Oct 10]. Available from: https://aps.saude.gov.br/ape/brasilsorridente

34. Righolt AJ, Jevdjevic M, Marcenes W, Listl S. Global-, Regional-, and country-level economic impacts of dental diseases in 2015. J Dent Res. 2018 May;97(5):501-7. https://doi.org/10.1177/0022034517750572

35. Almeida DO, Chaves SC, Souza RA, Soares FF. Outcome of single-vs multiple-visit endodontic therapy of nonvital teeth: a meta-analysis. J Contemp Dent Pract. 2017 Apr;18(4):330-6. https://doi.org/10.5005/ip-journals-10024-2041

36. Lima DC, Saliba NA, Moimaz SA. [Atraumatic restorative treatment and its use in public health dentistry]. RGO. 2008 Jan-Mar;56(1):75-9. Portuguese.

37. Ladewig NM, Camargo LB, Tedesco TK, Floriano I, Gimenez T, Imparato JC, et al. Management of dental caries among children: a look at the cost-effectiveness. Expert Rev Pharmacoecon Outcomes Res. 2018 Apr;18(2):127-34. https://doi.org/10.1080/14737167.2018.1414602

38. Calvo AF, Kicuti A, Tedesco TK, Braga MM, Raggio DP. Evaluation of the relationship between the cost and properties of glass ionomer cements indicated for atraumatic restorative treatment. Braz Oral Res. 2016;30(1):e8. https://doi.org/10.1590/1807-3107BOR-2016.vol30.0008

39. Kalsi JS, Hemmings K. The influence of patients' decisions on treatment planning in restorative dentistry. Dent Update. 2013 Nov; 40(9):698-700. https://doi.org/10.12968/denu.2013.40.9.698

40. Reis BS, Barbosa CC, Soares LC, Brum SC, Barbosa OL, Marques MM. [In vitro analysis of antimicrobial activity of ctz binder used as material plug in deciduous teeth pulp]. Revista Pró-UniverSUS. 2016;07(3):39-42. Portuguese.

41. Pinheiro HH, Assunção LR, Torres DK, Miyahara AK, Arantes DC. [Endodontic therapy in primary teeth by pediatric dentists]. Pesqui Bras Odontopediatria Clin Integr. 2013;13(4):351-60. Portuguese. https://doi.org/10.4034/PBOCI.2013.134.08

42. Abukabbos H, Tomar S, Guelmann M. Cost estimates for bioactive cement pulpotomies and crowns in primary molars. Pediatr Dent. 2018 Jan;40(1):51-5.

43. Pedrosa FAS, Silveira RR, Yamauti M, Castro CDL, Freitas ABDA. [Rubber Dam: use in private clinics in Belo Horizonte, MG, Brazil]. Pesq Bras Odontop Clin Integr. 2011;11(3):443-9. Portuguese. 